\title{
Phosphorylation of AKT serine/threonine kinase and abundance of milk protein synthesis gene networks in mammary tissue in response to supply of methionine in periparturient Holstein cows
}

\author{
Y. F. Ma, ${ }^{1,2}$ F. Batistel, ${ }^{3}$ T. L. Xu, ${ }^{4}$ L. Q. Han, ${ }^{5}$ R. Bucktrout, ${ }^{2}$ Y. Liang, ${ }^{2}$ D. N. Coleman, ${ }^{2}$ C. Parys, ${ }^{6}$ \\ and J. J. Loor ${ }^{2 *}$ \\ ${ }^{1}$ Institute of Animal Nutrition and Feed, Inner Mongolia Academy of Agriculture and Animal Husbandry Sciences, Hohhot 010031, P. R. China \\ ${ }^{2}$ Department of Animal Sciences and Division of Nutritional Sciences, University of Illinois, Urbana 61801 \\ ${ }^{3}$ Department of Animal, Dairy \& Veterinary Science, Utah State University, Logan 84322 \\ ${ }^{4}$ College of Veterinary Medicine, Nanjing Agricultural University, Nanjing, 210095, P. R. China \\ ${ }^{5}$ Department of Animal Science and Veterinary Medicine, Henan Agricultural University, Zhengzhou, 450002, P. R. China \\ ${ }^{6}$ Evonik Nutrition \& Care GmbH, Hanau-Wolfgang, 63457, Germany
}

\section{ABSTRACT}

The main objective was to evaluate the effect of increasing the supply of Met around parturition on abundance and phosphorylation of insulin- and mechanistic target of rapamycin complex 1 (mTORC1)-related signaling proteins along with mRNA abundance of milk protein and fat synthesis-related genes in postpartal mammary tissue. A basal control diet (control) or the basal diet plus ethyl-cellulose rumen-protected Met $(0.9 \mathrm{~g} / \mathrm{kg}$ of dry matter intake; Mepron, Evonik Nutrition \& Care GmbH, Hanau-Wolfgang, Germany) were fed ( $\mathrm{n}=30$ cows/diet $)$ from $\mathrm{d}-28$ to 60 relative to parturition. Mammary tissue and blood plasma were harvested from the same cows $(\mathrm{n}=5 /$ diet $)$ in the control and Met groups at d 21 postpartum for mRNA, protein, and AA analysis. Increasing the supply of Met led to greater milk protein percentage and milk yield along with greater ratio of phosphorylated (p-)AKT to total AKT. The ratio of p-mTORC1 to total mTORC1 did not differ, but ratio of p-RPS6 to total ribosomal protein S6 (RPS6) was lower in response to Met supply. These responses were associated with greater mRNA abundance of the signaling proteins Janus kinase 2 (JAK2) and insulin receptor substrate 1 (IRS1). Greater Met supply also upregulated mRNA abundance of high-affinity cationic (SLC7A1) and sodium-coupled AA transporters (SLC38A1, SLC38A2); leucyl-tRNA $(L A R S)$, valyl-tRNA (VARS), and isoleucyl-tRNA synthetases (IARS); glucose transport solute carrier family 2 member 3 (SLC2A1); glucose transport solute carrier family 2 member 3 (SLC2A3); and casein $\alpha$-s1 (CSN1S1). The mRNA abundance of components of

Received July 27, 2018.

Accepted January 25, 2019.

*Corresponding author: jloor@illinois.edu the unfolded protein response, such as $\mathrm{x}$-box binding protein 1 (XBP1) and activating transcription factor 6 (ATF6), were upregulated, and protein phosphatase 1, regulatory subunit 15A (PPP1R15A) was downregulated in response to greater Met supply. Overall, the data suggest that increased dry matter intake, greater phosphorylation status of AKT, upregulation of glucose and AA transporters, and transcripts of tRNases in response to enhanced Met supply might have compensated for a reduction in ribosome biogenesis due to a lower ratio of p-RPS6 to total RPS6. Together, these cellular responses constitute a mechanism whereby Met supply can regulate milk protein synthesis in early lactation.

Key words: lactation, transition period, amino acid, mammary gland

\section{INTRODUCTION}

Amino acids and glucose play important roles in the overall process of milk protein synthesis (Backwell et al., 1996). These nutrients provide energy and the building blocks for the protein synthetic machinery, and AA themselves can serve as signaling molecules to regulate this process (Dong et al., 2018). The importance of proper dietary balancing of EAA, and Met in particular, for milk protein synthesis in dairy cows was recently underscored by a large meta-analysis of published data (Lean et al., 2018). However, despite substantial work on the regulation of milk protein synthesis, knowledge of the intracellular signaling networks and their connections is in its infancy (Cant et al., 2018).

In the mammary gland, a clear relationship is present at the molecular level between EAA availability and insulin signaling on milk protein synthesis through changes in gene network expression (Bionaz and Loor, 2011; Loor et al., 2013), activity of the mechanistic tar- 
get of rapamycin complex 1 (mTORC1) pathway and related proteins (Appuhamy et al., 2011), or both (Cant et al., 2018). The role of the endoplasmic reticulum (ER) in protein synthesis, transport, and processing is well established in most eukaryotic cells (Malhotra and Kaufman, 2007) and the upregulation of this pathway in bovine mammary tissue was observed during lactation (Invernizzi et al., 2012). A recent review of the literature underscored the potential role of the components of the unfolded protein response (UPR) in the control of the cellular secretory phenotype that is often enhanced in response to EAA, glucose supply, or both (Cant et al., 2018).

Recent in vitro and in vivo studies with ruminant mammary cells provided evidence that AKT regulates de novo fatty acid synthesis via the mTORC1/ sterol regulatory element binding transcription factor 1 (SREBF1) axis (Li et al., 2016, 2018; Zhang et al., 2018). Thus, nutritional activation of mTORC1 or AKT could not only alter milk protein, but also mammary lipid synthesis, in part through upregulation of gene networks controlling those processes (Pauloin and Chanat, 2012; Caron et al., 2015; Zhang et al., 2018). Whether such relationships exist in bovine mammary tissue during early lactation when the cow experiences systemic insulin resistance is unknown.

We hypothesized that increasing Met supply stimulates milk protein synthesis during early lactation, not only through changes in protein and phosphorylation status of the mTORC1 pathway, but also through alterations in mRNA abundance of components of the milk protein and fat synthesis networks. The specific objective was to measure protein and mRNA abundance of a wide array of targets associated with milk protein and fat synthesis regulation using mammary biopsy tissue harvested from cows fed a control diet or the control supplemented with rumen-protected Met (RPM) in the study of Batistel et al. (2017). In addition, data from plasma AA profiles in plasma were used to evaluate potential effects on insulin sensitivity.

\section{MATERIALS AND METHODS}

\section{Experimental Design and Treatments}

The Institutional Animal Care and Use Committee at University of Illinois (Urbana; Institutional Animal Care and Use Committee protocol \#14270) approved all the experimental procedures. Details of the experimental design have been reported previously (Batistel et al., 2017). Briefly, 60 multiparous Holstein cows were used in a randomized, complete, unbalanced block design experiment with 30 cows per treatment. Treat- ment diets consisting of a basal control (control) diet with no added Met or the basal diet plus ethyl-cellulose RPM (Mepron, Evonik Nutrition \& Care GmbH, Hanau-Wolfgang, Germany) were fed from d -28 to 60 relative to parturition at a rate of 0.09 to $0.10 \%$ of DMI of the previous day during the prepartum (last 28 $\mathrm{d}$ of pregnancy) and postpartum (from parturition until 21 d postpartum) period, respectively. This supply of Met was based on recent experiments demonstrating a benefit of achieving a Lys:Met ratio close to 2.8:1 in terms of production performance and health (Osorio et al., 2013). Mepron, a source of commercial rumenprotected DL-Met, is resistant to rumen degradation by coating with ethyl cellulose film. Pellets measure $1.8 \times 3 \mathrm{~mm}$ and contain $85 \%$ DL-Met. The intestinal digestible coefficient and rumen bypass of Mepron is 90\% (Schwab, 1995) and 80\%, respectively (Overton et al., 1996). Therefore, per $10 \mathrm{~g}$ of Mepron, the cows received $6.1 \mathrm{~g}$ of Met available for absorption. During the preliminary period (from -45 to -29 d relative to the expected parturition day), all cows received the same diet with no added Met.

\section{Mammary Gland Biopsies}

Cows selected for biopsy from the control and Met groups were balanced by parity (3.5-3.6), day in prepartal diet (27-28), absence of clinical disorders, previous $305-\mathrm{d}$ milk yield $(10,260-11,186 \mathrm{~kg})$, and BCS [3.6-3.7; 1 to 5 scale $(1=$ thin, $5=$ fat $)$ ] at $-30 \mathrm{~d}$ before parturition. Mammary gland tissue was harvested on d 21 (n $=5 /$ diet) via percutaneous biopsy according to a published procedure from our laboratory (Bionaz and Loor, 2007). All biopsies were harvested at approximately $0700 \mathrm{~h}$ (after the morning milking). The procedure was conducted under mild general anesthesia with xylazine (Phoenix Pharmaceutical Inc., St. Joseph, MO; 0.75 $\mathrm{mL}$ total i.v.; $20 \%$ solution) and local anesthesia with lidocaine $\mathrm{HCl}(10 \mathrm{~mL}$ total s.c.; $2 \%$ solution). The midpoint area of left rear side of the udder was clipped and surgically scrubbed before biopsy. A 3-cm incision was made through the skin and subcutaneous tissue, which was afterward detached from the mammary capsule at the site of incision. A clear image of the capsule was always necessary to introduce the biopsy instrument to prevent it from tangling with the subcutaneous tissue. Approximately $150 \mathrm{mg}$ of tissue was removed after 4 punctures (per Institutional Animal Care and Use Committee guidelines) of 5 to $10 \mathrm{~cm}$ in depth using a biopsy needle (Bard Magnum, 12 gauge $\times 16 \mathrm{~cm}$; C. R. Bard Inc., Murray Hill, NJ). Tissue was blotted with gauze to remove excess blood and any connective tissue and then immediately snap-frozen in liquid nitrogen 
and stored at $-80^{\circ} \mathrm{C}$ until later analysis. Pressure was applied for $10 \mathrm{~min}$ to the incision area with sterile gauze to prevent excessive bleeding until visual signs of bleeding were absent. The skin incision was then closed with 3 Michel wound clips $(11 \mathrm{~mm}$; Henry Schein, Melville, NY; http://www.henryschein.com) using an applicator/remover also supplied by the same manufacturer. Antimicrobial ointment was applied to the incision site. The area surrounding the surgical site was cleaned with surgical soap and water to remove blood, taking care not to disturb the incision area. Clots resulting from the biopsies were removed by hand over $3 \mathrm{~d}$ postbiopsy. Cows did not experience clinical signs of disease at any point during the study.

\section{Western Blot Analysis}

Total protein was extracted using a tissue protein extraction reagent (catalog no. 78510, Thermo Scientific, Waltham, MA) containing inhibitor cocktail $(100 \times$, catalog no. 78442 , Thermo Scientific). Total protein concentration was determined using the BCA Assay Kit (catalog no. 23227, Thermo Scientific). Protein samples were boiled for $5 \mathrm{~min}$ at $100^{\circ} \mathrm{C} ; 50 \mathrm{~g}$ of total protein per lane was resolved by $10 \%$ SDS-PAGE (Bio-Rad, Hercules, CA) and then transferred from the gel to a polyvinylidene difluoride membrane $(0.45 \mu \mathrm{m}$, Millipore, Billerica, MA; catalog no. 1620261) by using the semi-dry transfer assembly (Bio-Rad). PageRuler Plus Prestained Protein Ladder (Fermentas, Hanover, MD) was used to confirm protein electrophoresis. Membranes were blocked in Tris-buffered saline (TBST; $50 \mathrm{~m} M$ Tris, $\mathrm{pH}$ 7.6, $150 \mathrm{mM} \mathrm{NaCl}$, and $0.1 \%$ Tween 20 ), which contains $5 \%$ (wt/vol) nonfat dry milk for $2 \mathrm{~h}$ at room temperature with gentle agitation. The membranes were then incubated in TBST containing antibodies to mTORC1 (catalog no. ab2732, Abcam, Cambridge, MA), p-mTORC1 (catalog no. ab84400, Abcam), RPS6KB1 (catalog no. ab9366, Abcam), pRPS6KB1 (catalog no. ab2571, Abcam), AKT (catalog no. ab8805, Abcam), p-AKT (catalog no. ab38449, Abcam), RPS6 (catalog no. ab40820, Abcam), p-RPS6 (catalog no. ab12864, Abcam), EIF4EBP1 (catalog no. ab2606, Abcam), p-EIF4EBP1 (catalog no. ab75767, Abcam), EIF2A (catalog no. ab5369, Abcam), p-EIF2A (catalog no. ab32157, Abcam), EEF2 (catalog no. ab33523, Abcam), and p-EEF2 (catalog no. ab53114, Abcam) with gentle agitation at $4^{\circ} \mathrm{C}$ overnight. After incubating with primary antibody, the membranes were washed and incubated with anti-rabbit horseradish peroxidase-conjugated secondary antibodies (catalog no. ab6721, Abcam) in TBST for $1 \mathrm{~h}$ at room temperature. The membranes were washed and then incubated with ECL reagent (catalog no. 170-5060, Bio-Rad). Glyceraldehyde 3-phosphate dehydrogenase (catalog no. ab22555, Abcam) was used as the internal control. The images were captured using Chemi DOC MP (BioRad). The intensities of the bands were measured with Image-Pro Plus 6.0 software (Media Cybernetics Inc., Rockville, MD).

\section{RNA Isolation, cDNA Synthesis, and Quantitative PCR}

Total RNA was isolated from $50 \mathrm{mg}$ of mammary gland tissue using the miRNeasy kit (Qiagen, Hilden, Germany) following the manufacturer's protocols. Samples were treated on-column with DNaseI (Qiagen); quantification was accessed using the NanoDrop ND-1000 (NanoDrop Technologies, Wilmington, DE), and RNA quality was measured using an Agilent 2100 Bioanalyzer (Agilent, Santa Clara, CA). All samples had an RNA integrity number factor greater than 7.3. The quantitative (q)PCR was performed as described previously (Osorio et al., 2014) to determine relative mRNA abundance of target genes. The genes for study encompassed a subset of those measured by Bionaz and Loor (2011) in bovine mammary tissue across the lactation cycle, and those proposed by Cant et al. (2018) as playing a key role in the nutritional regulation of milk protein synthesis. RPS9, RPS15, and UXT were selected as the internal control genes to normalize mRNA abundance data (Bionaz and Loor, 2007). All reactions were run in triplicate. Primer pairs used have been reported previously (Bionaz and Loor, 2008, 2011).

\section{Plasma AA Analysis}

Blood was sampled from the same cows used for biopsies from the coccygeal vessel before feeding at d 21 relative to calving date. Samples were collected into evacuated tubes (BD Vacutainer, BD and Co., Franklin Lakes, NJ) containing lithium heparin, and immediately placed on ice before centrifugation at 2,000 $\times g$ for $30 \mathrm{~min}$ at $4^{\circ} \mathrm{C}$ to obtain plasma. Aliquots of plasma were frozen $\left(-80^{\circ} \mathrm{C}\right)$ until further analysis. Amino acid analysis was performed according to established protocols (AOAC International, 1995). Briefly, samples were first oxidized at $0^{\circ} \mathrm{C}$ for $16 \mathrm{~h}$ with performic acid to allow for subsequent quantification of Met and Cys. Excess performic acid was removed with an incubation with sodium sulfite for 30 min in an ice bath. Hydrolysis was then performed with hydrochloric acid at $110^{\circ} \mathrm{C}$ for $24 \mathrm{~h}$. A Biochrom 30+ (Biochrom Ltd., Cambridge, UK) AA analyzer was used for AA profiling. 


\section{Statistical Analysis}

The mRNA and protein abundance, and plasma AA data were analyzed using the MIXED procedure of SAS v.9.4 (SAS Institute Inc., Cary, NC) according to the following model:

$$
Y_{i j}=\mu+b_{i}+M_{j}+A_{k: i j}+e_{i j k}
$$

where $Y_{i j}=$ dependent, continuous variable; $\mu=$ overall mean; $b_{i}=$ random effect of block; $M_{j}=$ fixed effect of treatment ( $j=$ control vs. Met); $A_{k: i j}=$ random effect of cow nested within block and treatment; and $e_{i j k}=$ residual error. Normality of the residuals was checked with Shapiro-Wilk test $P$-values, box plots, and homogeneity of variances with plots of residuals versus predicted values. Significance was determined at $P \leq$ 0.05 and tendencies at $P \leq 0.10$.

\section{RESULTS AND DISCUSSION}

In a companion manuscript with the entire cohort of cows, we reported the beneficial effects of enhancing Met supply by feeding ethyl-cellulose RPM on milk yield $(+4.1 \mathrm{~kg} / \mathrm{d}$ until 21 DIM; control mean, $37.1 \mathrm{~kg} / \mathrm{d}$ and Met mean $41.2 \mathrm{~kg} / \mathrm{d})$, milk protein yield $(+0.2 \%$ units until 21 DIM), and DMI $(+1.7 \mathrm{~kg} / \mathrm{d}$ until 21 DIM; Batistel et al., 2017). Similar differences were detected in the biopsied cows fed Met $(P<0.05)$ with milk yield and DMI for the cows biopsied averaging 37.2 versus $33.7 \pm 0.78 \mathrm{~kg} / \mathrm{d}$, and 16.5 versus $14.8 \pm \mathrm{kg} / \mathrm{d}$, respectively, during the first 21 DIM. In addition, milk protein percentage was greater $(P=0.02)$ in Met cows averaging 3.45 versus $3.33 \pm 0.04 \%$. These responses agree with previous data from cows supplemented RPM during the periparturient period (Osorio et al., 2013; Zhou et al. (2016a,b). The present study specifically addressed the potential role of mTORC1 and insulin signaling pathways in coordinating the response in milk protein synthesis induced by enhancing the Met supply. Although milk fat percentage was not affected by Met supply in the entire cohort (Batistel et al., 2017), or biopsied cows (3.97 vs. $4.09 \pm 0.11 \%$ in Met vs. controls, $P=0.35$ ), we sought to evaluate any changes in lipogenic gene networks that have been associated with mTORC1 signaling in nonruminants (Porstmann et al., 2008) and ruminants (Li et al., 2016; Zhang et al., 2018).

Glucose tolerance tests underscored the progressive development of insulin resistance in dairy cows during the peripartum (Mann et al., 2016). Glucose availability to mammary gland is an important regulator of milk lactose synthesis, which is the main driver of milk volume (Zhao and Keating, 2007). Insulin resistance in tissues like skeletal muscle and adipose during early lactation effectively channels glucose to the mammary gland to support lactose synthesis (De Koster et al., 2018). The abundance of AKT has been used in vitro and in vivo as a proxy (or indicator) of insulin sensitivity in studies with dairy cow adipose tissue (Zachut et al., 2013; De Koster et al., 2018; Rico et al., 2018). Thus, we speculate that the greater ratio of p-AKT: AKT $(P<0.05$; Table 1$)$ is suggestive of increased insulin sensitivity in the mammary gland.

The greater abundance of p-AKT:total-AKT (Table $1)$, and the upregulation of $\operatorname{IRS} 1(P \leq 0.03$; Table 2) in cows fed Met are suggestive of enhanced insulin sensitivity in the mammary gland. However, the mRNA abundance of the insulin-sensitive transporters $S L C 2 A 4$ and SLC2A 8 did not differ (Table 2). In contrast, the abundance of SLC2A1 $(P=0.05)$ and SLC2A3 $(P=$ $0.03)$, the most abundant glucose transporters in the bovine mammary gland during the lactation cycle (Bionaz and Loor, 2011), was upregulated in cows fed Met. Glucose transport in cells occurs by facilitated diffusion along a concentration gradient through the glucose transporters (formerly GLUT) embedded in lipid bilayers (Zhao, 2014), including GLUT1 (SLC2A1), GLUT3 (SLC2A3), the insulin-sensitive GLUT4 (SLC2A4), and GLUT8 (SLC2A8). Whereas GLUT3, GLUT4, and GLUT8 are expressed in the lactating bovine mammary gland, GLUT1 is the most abundant transporter (Zhao and Keating, 2007). The GLUT8 is a member of the facilitative glucose transporter family, and its mRNA increases from late pregnancy to early lactation, indicating that it may play a role in milk synthesis (Zhao et al., 2004; Zhao and Keating, 2007).

If, in fact, greater p-AKT:AKT reflected enhanced insulin signaling within mammary tissue, the lower $(P<0.05$; Table 3$)$ plasma concentrations of NEAA (Tucker et al., 2017), along with lower His $(P<0.05$; Table 3; Giallongo et al., 2016) in response to Met might have contributed to promoting greater rates of milk protein synthesis (Batistel et al., 2017). The positive effect of insulin on milk protein percentage and yield during euglycemia in mid to late lactation has been reported previously (McGuire et al., 1995). During early lactation, subcutaneous injection of long-acting insulin increased milk protein content in dairy cows (Winkelman and Overton, 2013). During early lactation when there is increased peripheral insulin resistance, the high anabolic demand of the mammary gland has priority over the uptake of circulating AA in other key organs such as the liver (Galindo et al., 2015). Amino acid transporters such as the $\mathrm{Na}^{+}$-independent solute carrier family 7 member 1 (SLC7A1) and solute carrier family 38 member 1 (SLC38A1), and $\mathrm{Na}^{+}$-dependent solute carrier family 38 member 2 (SLC38A2) play important 
Table 1. Protein abundance (relative to GAPDH) of components in the insulin and mechanistic target of rapamycin complex 1 (mTORC1) signaling pathways in mammary tissue at $21 \mathrm{~d}$ postpartum ${ }^{1}$

\begin{tabular}{|c|c|c|c|c|c|}
\hline \multirow[b]{2}{*}{ Item $^{2}$} & \multicolumn{2}{|c|}{ Diet } & \multirow{2}{*}{$\begin{array}{c}\% \\
\text { Difference }^{3}\end{array}$} & \multirow[b]{2}{*}{ SEM } & \multirow[b]{2}{*}{$P$-value } \\
\hline & Control & $\mathrm{Met}^{4}$ & & & \\
\hline \multicolumn{6}{|l|}{ Total protein } \\
\hline $\mathrm{AKT}$ & 1.38 & 1.04 & -24.6 & 0.10 & 0.04 \\
\hline mTORC1 & 0.98 & 0.52 & -46.9 & 0.04 & $<0.01$ \\
\hline EIF4EBP1 & 1.04 & 1.28 & 23.1 & 0.08 & 0.08 \\
\hline RPS6KB1 & 0.41 & 0.46 & 12.2 & 0.06 & 0.60 \\
\hline RPS6 & 1.64 & 1.28 & -22.0 & 0.10 & 0.03 \\
\hline EIF2A & 0.59 & 0.54 & -8.5 & 0.04 & 0.35 \\
\hline EEF2 & 0.96 & 0.61 & -36.5 & 0.11 & 0.05 \\
\hline \multicolumn{6}{|c|}{ Phosphorylated (p-) protein } \\
\hline $\mathrm{p}-\mathrm{AKT}$ & 1.28 & 1.32 & 3.1 & 0.13 & 0.81 \\
\hline p-mTORC1 & 1.14 & 0.69 & -39.5 & 0.07 & $<0.01$ \\
\hline p-EIF4EBP1 & 0.84 & 1.09 & 29.8 & 0.12 & 0.17 \\
\hline p-RPS6KB1 & 0.47 & 0.58 & 23.4 & 0.10 & 0.43 \\
\hline p-RPS6 & 1.22 & 0.61 & -50.0 & 0.07 & $<0.01$ \\
\hline p-EIF2A & 0.12 & 0.09 & -25.0 & 0.01 & 0.17 \\
\hline p-EEF2 & 0.97 & 0.82 & -15.5 & 0.13 & 0.42 \\
\hline \multicolumn{6}{|c|}{ Ratio of phosphorylated:total } \\
\hline p-AKT:AKT & 0.94 & 1.28 & 36.2 & 0.11 & 0.05 \\
\hline p-mTORC1:mTORC1 & 1.17 & 1.37 & 17.1 & 0.18 & 0.47 \\
\hline p-EIF4EB1:EIF4EB1 & 0.79 & 0.85 & 7.6 & 0.08 & 0.63 \\
\hline p-RPS6KB1:RPS6KB1 & 1.12 & 1.27 & 13.4 & 0.11 & 0.38 \\
\hline p-RPS6:RPS6 & 0.74 & 0.47 & -36.5 & 0.03 & $<0.01$ \\
\hline p-EIF2A:EIF2A & 0.20 & 0.16 & -20.0 & 0.03 & 0.26 \\
\hline p-EEF $2: E E F 2$ & 1.03 & 1.33 & 29.1 & 0.11 & 0.09 \\
\hline
\end{tabular}

${ }^{1}$ Holstein cows were fed a basal diet (control prepartum diet, $1.47 \mathrm{Mcal} / \mathrm{kg}$ of DM and $15.3 \% \mathrm{CP}$; control postpartum diet, $1.67 \mathrm{Mcal} / \mathrm{kg}$ of $\mathrm{DM}$ and $17.7 \% \mathrm{CP}$ ) or control plus ethyl-cellulose rumen-protected Met at a rate of $0.09 \%$ and $0.10 \%$ of DMI from -28 to calving and from 1 through $60 \mathrm{~d}$ postcalving. Data are LSM, $\mathrm{n}=5$ cows per diet, \pm pooled SEM.

${ }^{2} \mathrm{AKT}=$ protein kinase $\mathrm{B} ; \mathrm{mTORC} 1=$ mechanistic target of rapamycin complex 1 ; EIF4EBP1 = eukaryotic translation initiation factor 4E binding protein 1; RPS6KB1 = ribosomal protein S6 kinase B1; RPS6 = ribosomal protein S6; EIF2A = eukaryotic translation initiation factor 2A; EEF2 = eukaryotic translation elongation factor 2 .

${ }^{3}$ Difference in mRNA abundance $=($ Met - control $) /$ control $\times 100$.

${ }^{4}$ Mepron (Evonik Nutrition \& Care GmbH, Hanau-Wolfgang, Germany).

Table 2. mRNA abundance (log-2 scale) of glucose transporters and components of the insulin and Janus kinase (JAK)-signal transducer and activator of transcription (STAT) signaling pathway in mammary tissue at $21 \mathrm{~d}$ postpartum ${ }^{1}$

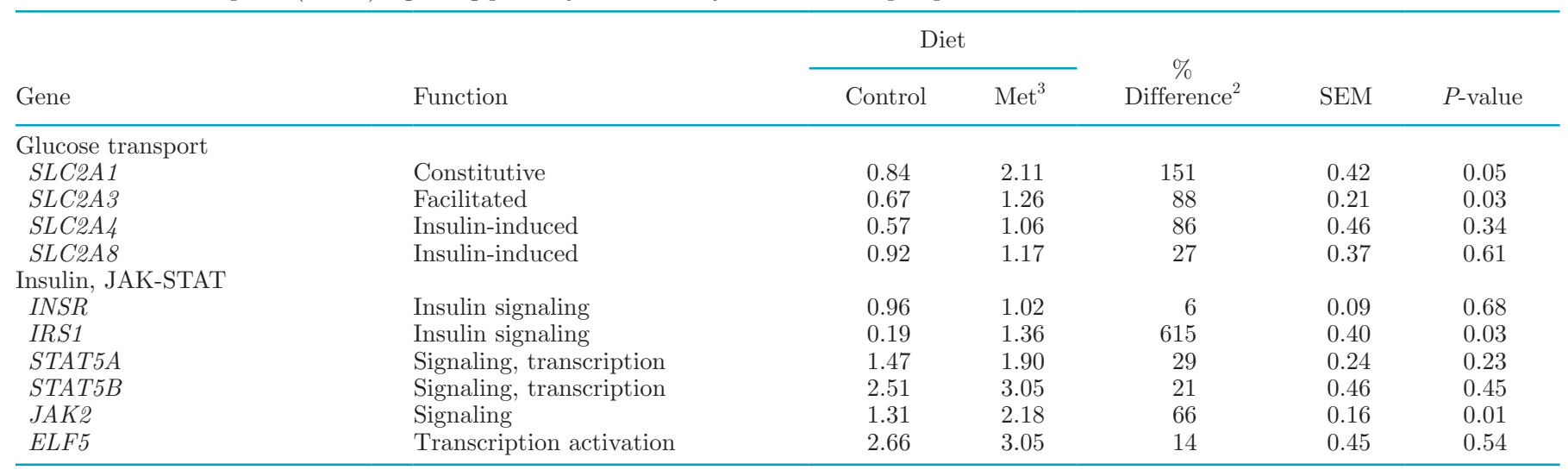

${ }^{1}$ Holstein cows were fed a basal diet (control prepartum diet, $1.47 \mathrm{Mcal} / \mathrm{kg}$ of DM and $15.3 \% \mathrm{CP}$; control postpartum diet, $1.67 \mathrm{Mcal} / \mathrm{kg}$ of $\mathrm{DM}$ and $17.7 \% \mathrm{CP}$ ) or control plus ethyl-cellulose rumen-protected Met at a rate of $0.09 \%$ and $0.10 \%$ of DMI from -28 to calving and from 1 through 60 d postcalving. Data are LSM, $\mathrm{n}=5$ cows per diet, \pm pooled SEM.

${ }^{2}$ Difference in mRNA abundance $=($ Met - control $) /$ control $\times 100$.

${ }^{3}$ Mepron (Evonik Nutrition \& Care GmbH, Hanau-Wolfgang, Germany). 
Table 3. Plasma concentrations $(\mu \mathrm{mol} / \mathrm{L})$ of AA at $21 \mathrm{~d}$ postpartum ${ }^{1}$

\begin{tabular}{|c|c|c|c|c|c|}
\hline \multirow[b]{2}{*}{ AA } & \multicolumn{2}{|c|}{ Diet } & \multirow{2}{*}{$\begin{array}{c}\% \\
\text { Difference }^{2}\end{array}$} & \multirow[b]{2}{*}{ SEM } & \multirow[b]{2}{*}{$P$-value } \\
\hline & Control & $\mathrm{Met}^{3}$ & & & \\
\hline Met & 10.1 & 11.3 & 12.4 & 1.87 & 0.65 \\
\hline Cys & 0.8 & -4 & -100 & 0.37 & 0.18 \\
\hline Lys & 60.1 & 57.1 & -5.0 & 4.2 & 0.62 \\
\hline Thr & 71.3 & 58.8 & -17.5 & 7.6 & 0.25 \\
\hline Arg & 54.2 & 49.2 & -9.2 & 4.8 & 0.47 \\
\hline Ile & 112 & 124 & 10.2 & 15.2 & 0.60 \\
\hline Leu & 152 & 159 & 4.6 & 19 & 0.80 \\
\hline Val & 245 & 265 & 8.2 & 32 & 0.66 \\
\hline His & 39.9 & 31.5 & -21.1 & 2.9 & 0.05 \\
\hline Phe & 36.1 & 42.3 & 17.2 & 2.7 & 0.11 \\
\hline Gly & 431 & 309 & -28.3 & 36.7 & 0.02 \\
\hline Ser & 84.2 & 61.5 & -27.0 & 7.4 & 0.04 \\
\hline Pro & 76.2 & 67.5 & -11.4 & 5.6 & 0.27 \\
\hline Ala & 201 & 178 & -11.4 & 15.7 & 0.29 \\
\hline Asp & 7.9 & 10.6 & 34.3 & 1.73 & 0.27 \\
\hline Glu & 35.2 & 41.4 & 17.6 & 4.55 & 0.34 \\
\hline Taurine & 31.6 & 24.5 & -22.5 & 3.42 & 0.15 \\
\hline Asn & 41.7 & 30.2 & -27.6 & 3.7 & 0.04 \\
\hline Gln & 186 & 151 & -18.9 & 9.85 & 0.02 \\
\hline Tyr & 39.0 & 34.4 & -11.8 & 3.2 & 0.32 \\
\hline $\mathrm{BCAA}^{5}$ & 509 & 547 & 7.5 & 66.2 & 0.68 \\
\hline $\mathrm{NEAA}^{6}$ & 1,189 & 957 & -19.5 & 97.0 & 0.02 \\
\hline $\mathrm{EAA}^{7}$ & 726 & 748 & 3.0 & 85.4 & 0.84 \\
\hline Total & 1,915 & 1,705 & -11 & 182 & 0.32 \\
\hline
\end{tabular}

${ }^{1}$ Holstein cows were fed a basal diet (control prepartum diet, $1.47 \mathrm{Mcal} / \mathrm{kg}$ of DM and $15.3 \% \mathrm{CP}$; control postpartum diet, $1.67 \mathrm{Mcal} / \mathrm{kg}$ of $\mathrm{DM}$ and $17.7 \% \mathrm{CP}$ ) or control plus ethyl-cellulose rumen-protected Met at a rate of 0.09 and $0.10 \%$ of DMI from -28 to calving and from 1 through $60 \mathrm{~d}$ postcalving. Data are LSM, n $=5$ cows per diet, \pm pooled SEM.

${ }^{2}$ Difference in concentration $=($ Met - control $) /$ control $\times 100$.

${ }^{3}$ Mepron (Evonik Nutrition \& Care GmbH, Hanau-Wolfgang, Germany).

${ }^{4}$ Not detected.

${ }^{5} \Sigma$ branched-chain.

${ }^{6} \Sigma$ nonessential.

${ }^{7} \Sigma$ essential.

roles in tissue AA uptake (Closs et al., 2006; Sundberg et al., 2008). For example, SLC27A1 transports cationic L-AA (His, Arg, and Lys; Closs et al., 2006). The SLC38A1 and SLC38A2 transport neutral-AA such as Ala, Ser, Gly, Pro, Cys, and Gln (Mackenzie and Erickson, 2004; Manjarin et al., 2014). The abundance of SLC7A1, SLC38A1, and SLC38A2 along with CSN1S1 was upregulated in response to enhanced Met supply $(P$ $\leq 0.03$; Table 4). Thus, coupled with the lower plasma NEAA and His concentrations, these responses may have contributed to greater milk protein percentage and yield in cows with enhanced Met supply (Batistel et al., 2017).

In the current study, both total mTORC1 and pmTORC1 were lower $(P<0.01$; Table 1$)$ in response to Met supply, whereas the ratio of p-mTORC1:mTORC1 did not differ $(P=0.47$; Table 1$)$. In nonruminants, various AA are well-known regulators of mTORC1 activation, and we demonstrated previously that several mTORC1-related AA transporters reached peak
mRNA abundance in mammary tissue at 15 to $30 \mathrm{~d}$ postpartum (Bionaz and Loor, 2011). Hence, the lack of change $(P>0.19)$ in abundance of SLC1A5, SLC3A2, SLC7A5, and SLC36A1 (Table 4) supports the similar mTORC1 phosphorylation status in the present study. It is, however, somewhat paradoxical that expression of SLC38A1, SLC38A2, and SLC38A9 was upregulated ( $P$ $<0.05)$ in Met cows because there is evidence of a link with mTORC1 activity. For instance, in placenta from intrauterine growth-restricted animals not only activity of mTORC1 decreased but also the abundance of SLC38A2 (Chen et al., 2015) and SLC38A1 (Rosario et al., 2016). In contrast, abundance of SLC38A2 was upregulated by signals that induce an intracellular stress response [e.g., nutrient deprivation (Nardi et al., 2015)]. Although not strictly classified as an AA transporter, SLC38A9 is a lysosome-surface "sensor" of AA with a well-established role in nonruminants as an activator of mTORC1 when concentrations of Arg (in particular) increase (Wolfson and Sabatini, 2017). In that con- 
text, it is noteworthy that the plasma membrane Arg transporter SLC7A1 (Abdelmagid et al., 2011) also was upregulated $(P=0.02$, Table 4$)$ in cows fed Met. Not only does insulin stimulate Arg transport via SLC7A1 in vitro in certain cell types (González et al., 2011), but the abundance of this transporter has also been linked with greater production of nitric oxide in vitro (Cui et al., 2011), a potent signal that can enhance mammary blood flow rate in dairy cows (Lacasse et al., 1996).

Clearly, data from ruminants and nonruminants underscore the complexity of mTORC1 regulation as well as mammary utilization of certain AA for purposes other than milk protein synthesis (e.g., Arg and nitric oxide synthesis). In the context of the present study, it could be possible that "metabolic stress" within mammary gland during the process of copious milk synthesis and secretion is one of the triggers that control abundance or activity (or both) of certain AA transporters such as SLC38A1 and SLC38A2. It is also possible that other mechanisms besides cellular stress and mTORC1 activity regulate AA abundance. For instance, in vitro work with the ubiquitin ligase NEDD4L demonstrated that its activation can target SLC38A1 and SLC38A2 for proteasomal degradation (Rosario et al., 2016). Activity of the branched-chain $\alpha$-keto acid dehydrogenase complex, which plays a key role in branched-chain amino acid (BCAA) catabolism (Shimomura et al., 2006), could also dictate or help control the uptake of BCAA. Although the present study did not seek to address all likely mechanisms relating mTORC1 activity and AA transport when enhanced Met supply increased milk yield and milk protein synthesis, the

Table 4. mRNA abundance (log-2 scale) of selected AA transporters and sensors, transfer RNA (tRNA) synthesis, casein, and components of the endoplasmic reticulum (ER) stress pathway in mammary tissue at $21 \mathrm{~d}$ postpartum ${ }^{1}$

\begin{tabular}{|c|c|c|c|c|c|c|}
\hline Gene symbol & Function & \multicolumn{2}{|c|}{ Diet } & $\begin{array}{c}\% \\
\text { Difference }^{2}\end{array}$ & SEM & $P$-value \\
\hline \multicolumn{7}{|l|}{ AA transport } \\
\hline SLC1A5 & Neutral AA & 0.49 & 0.86 & 75 & 0.19 & 0.20 \\
\hline SLC3A2 & L-type & 0.42 & 0.51 & 21 & 0.18 & 0.37 \\
\hline SLC7A1 & $\mathrm{Na}^{+}, \mathrm{y}+$ cationic $\mathrm{AA}$ & 0.01 & 0.04 & 300 & 0.01 & 0.02 \\
\hline SLC38A1 & Gln & 0.73 & 2.83 & 287 & 0.42 & 0.02 \\
\hline SLC38A2 & Ala & 0.34 & 1.56 & 358 & 0.40 & 0.03 \\
\hline SLC43A1 & Neutral AA, L-type & 0.92 & 1.10 & 19 & 0.22 & 0.58 \\
\hline \multicolumn{7}{|l|}{ AA sensing } \\
\hline SLC38A9 & Arg & 0.39 & 1.48 & 279 & 0.16 & $<0.01$ \\
\hline$T A S 1 R 1$ & L-type & 2.76 & 3.24 & 17 & 0.19 & 0.10 \\
\hline TAS1R3 & L-type & 1.68 & 2.62 & 56 & 1.11 & 0.57 \\
\hline$V A R S$ & Histidyl-tRNA synthetase & 0.55 & 1.42 & 158 & 0.18 & 0.01 \\
\hline$I A R S$ & Isoleucyl-tRNA synthetase & 0.34 & 1.07 & 214 & 0.20 & 0.02 \\
\hline \multicolumn{7}{|l|}{ Caseins } \\
\hline CSN1S1 & Alpha casein & 1.12 & 2.68 & 139 & 0.25 & $<0.01$ \\
\hline CSN2 & Beta casein & 0.81 & 2.03 & 150 & 0.65 & 0.22 \\
\hline CSN3 & Kappa casein & 0.95 & 1.72 & 81 & 0.57 & 0.37 \\
\hline \multicolumn{7}{|l|}{ ER stress ${ }^{4}$} \\
\hline$X B P 1$ & ER stress transcription factor & 0.24 & 0.59 & 145 & 0.13 & 0.02 \\
\hline EIF2AKЗ & Translation inhibition & 0.69 & 1.47 & 113 & 0.49 & 0.15 \\
\hline HSPA 5 & ER protein assembly & 1.51 & 1.14 & -24 & 0.47 & 0.53 \\
\hline BHLHA15 & Transcription inhibition & 1.31 & 0.55 & -58 & 0.40 & 0.34 \\
\hline DDIT3 & ER stress transcription factor & 0.80 & 1.02 & 27 & 0.30 & 0.58 \\
\hline PPP1R15A & Reverses protein translation inhibition & 1.59 & 0.93 & -41 & 0.25 & 0.04 \\
\hline ATF6 & Transcriptional repressor & 0.64 & 1.47 & 129 & 0.30 & 0.03 \\
\hline
\end{tabular}

${ }^{1}$ Holstein cows were fed a basal diet (control prepartum diet, $1.47 \mathrm{Mcal} / \mathrm{kg}$ of DM and $15.3 \% \mathrm{CP}$; control postpartum diet, $1.67 \mathrm{Mcal} / \mathrm{kg}$ of $\mathrm{DM}$ and $17.7 \% \mathrm{CP}$ ) or control plus ethyl-cellulose rumen-protected Met at a rate of $0.09 \%$ and $0.10 \%$ of DMI from -28 to calving and from 1 through $60 \mathrm{~d}$ postcalving. Data are LSM, $\mathrm{n}=5$ cows per diet, \pm pooled SEM.

${ }^{2}$ Difference in mRNA abundance $=($ Met - control $) /$ control $\times 100$.

${ }^{3}$ Mepron (Evonik Nutrition \& Care GmbH, Hanau-Wolfgang, Germany).

${ }^{4}$ Based on the proposed network from Cant et al. (2018). 
data reported should help direct future studies that can address mechanistic aspects more specifically.

Phosphorylation of ribosomal protein S6 (RPS6), an indicator of mTORC1 activity, facilitates translation initiation (Wullschleger et al., 2006). The RPM supply resulted in lower $(P<0.05$; Table 1$)$ abundance of total RPS6 and p-RPS6, and lower ratio of p-RPS6 to RPS6. Toerien et al. (2010) hypothesized that milk protein synthesis is partly regulated by mTOCR1 and integrated stress response networks in the bovine mammary gland. This was based on data indicating that feedrestricted lactating cows receiving abomasal infusions of EAA produced less milk protein than those infused with EAA + Glu (Toerien et al., 2010). The benefit of energy, rather than casein alone, on milk protein synthesis during nutrient restriction was underscored in a subsequent study (Rius et al., 2010). Clearly, during periods of nutrient restriction, energy availability is important for milk protein synthesis. Thus, together, the present and previous data suggest that milk protein synthesis in early lactation may not be exclusively regulated through mTORC1. As such, we speculate that the greater milk protein percentage and yield in cows fed Met (Batistel et al., 2017) might be partly driven by increased feed intake, enhanced insulin sensitivity of the mammary tissue, and the ensuing increase in AA uptake rather than the sole activation of RPS6.

Despite enhancing the long-term supply of Met to mammary gland, the abundance of MARS in cows fed RPM did not differ $(P=0.54$, Table 4$)$, but the abundance of other EAA tRNases, genes encoding for enzymes that synthesize tRNA, such as $L A R S$, VARS, and IARS (Table 4), was upregulated $(P \leq 0.03)$. Some evidence indicates that ligation of AA via the ATP-dependent activity of tRNA-synthases serves as a longer-term mechanism channeling AA toward protein synthesis (Lee et al., 2004). If such scenario exists in bovine mammary cells, as long as there is a sustained supply of Met (via exogenous dietary supply) coupled with charging to RNA by the methionyl-tRNA synthetase MARS, formation of the translational complex that includes nonphosphorylated EIF2A, guanosine triphosphate, and MARS can occur and sustain further rounds of translation initiation (Lee et al., 2004).

The upregulation $(P \leq 0.03)$ of the ER stress response genes $X B P 1$ and $A T F 6$ coupled with the downregulation $(P \leq 0.04)$ of $P P P 1 R 15 A$ (Table 4$)$ in cows fed Met suggested an association between enhanced Met supply and ER mechanisms that are important for mammary secretory cell function (Cant et al., 2018). However, the lack of difference in phosphorylation status of EIF2A ( $P=0.26$; Table 1$)$ between Met and control cows seems to cast doubt on that association. At least in nonruminants, the phosphorylation status of pancreatic ER kinase and EIF2A is a key indicator of ER stress activation (Özcan et al., 2004). Alterations in signaling proteins that participate in the ER stress response are thought to activate the UPR, leading to a decrease or complete halt in protein synthesis (Ron and Walter, 2007). Because an increase in protein synthesis per se can trigger the UPR (Kaufman et al., 2002), at least in nonruminants, it is possible that the upregulation of XBP1 and ATF6 ( $P \leq 0.03$, Table 4$)$ was associated with the greater rate of milk protein synthesis in Met cows.

We previously reported that some transcriptional components of the ER stress response are associated with secretory AA transport, apoptosis, and ER lumen protein assembly/folding were upregulated $[\mathrm{CHOP}$ (currently DDIT3), EIF2AK3, CHOP, HSPA5] in mammary tissue after parturition $(\mathrm{d} 1,15,60$, or 240 vs. -15 ; Invernizzi et al., 2012). Those data led us to propose that the sudden change in metabolic activity of the gland at parturition to support milk component synthesis induces a pseudo UPR state (Invernizzi et al., 2012). Thus, transcriptional changes in the ER stress pathway at different stages of the lactation cycle are a normal aspect of the tissue's adaptation to the changing physiological state. The lack of change $(P>0.05)$ in abundance of DDIT3, EIF2AK3, HSPA5, ATF3 and basic helix-loop-helix family member A15 (BHLHA15) in response to enhanced Met supply (Table 4) suggests an absence of cellular stress, per se. In fact, abundance of BHLHA15 is a specific indicator of mammary secretory cell differentiation (Zhao et al., 2006). The greater ratio of p-AKT:total-AKT in Met cows, which is inhibited during chronic ER stress (Hosoi et al., 2007), offers further support for the role of XBP1 and ATF6 in the normal process of ER biogenesis and secretory cell function, both of which can be enhanced by Met supply.

The lack of change $(P>0.05)$ in mRNA abundance of genes related to milk fat synthesis regulation (FASN, $A C A C A, P P A R G$, and SREBF1) in response to Met supply (Table 5) agrees with the similar response in milk fat percentage (Batistel et al., 2017). In nonruminants, it is well established that insulin can promote hepatic lipogenesis (liver being the main lipogenic organ) either through direct activation of SREBF1 or indirectly via IRS-AKT activation of MTOR (Yecies et al., 2011). Lipogenesis via mTORC1 is related to AKT-mediated phosphorylation of mTORC1, followed by upregulation of SREBF1 (Yecies et al., 2011). Despite the greater abundance of p-AKT relative to total AKT in cows fed Met (Table 1), it is possible that the lack of effect on lipogenic genes in those cows was associated with the lower abundance of p-mTORC1 and total mTORC1 (Table 1). Further research should be conducted to ex- 
Table 5. mRNA abundance (log-2 scale) of genes associated with long-chain fatty acid uptake, de novo lipogenesis, desaturation, acetate, and ketone body utilization in mammary tissue at $21 \mathrm{~d}_{\text {postpartum }}{ }^{1}$

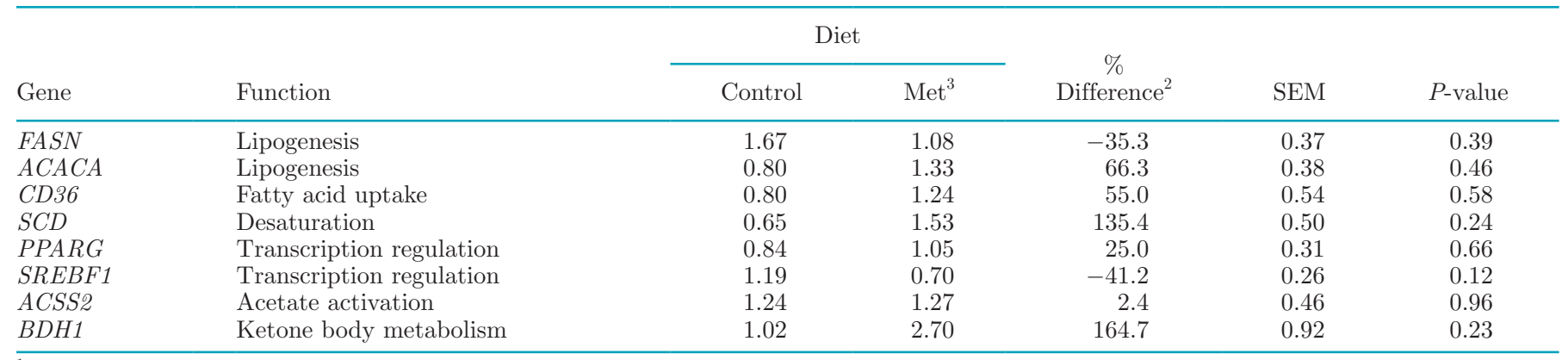

${ }^{1}$ Holstein cows were fed a basal diet (control prepartum diet, $1.47 \mathrm{Mcal} / \mathrm{kg}$ of DM and $15.3 \% \mathrm{CP}$; control postpartum diet, $1.67 \mathrm{Mcal} / \mathrm{kg}$ of DM and $17.7 \% \mathrm{CP}$ ) or control plus ethyl-cellulose rumen-protected Met at a rate of 0.09 and $0.10 \%$ of DMI from - 28 to calving and from 1 through $60 \mathrm{~d}$ postcalving. Data are LSM, $\mathrm{n}=5$ cows per diet, \pm pooled SEM.

${ }^{2}$ Difference in mRNA abundance $=($ Met - control $) /$ control $\times 100$.

${ }^{3}$ Mepron (Evonik Nutrition \& Care GmbH, Hanau-Wolfgang, Germany).

plore potential mechanistic relationships between milk protein and fat synthesis via mTORC1.

\section{CONCLUSIONS}

The lower phosphorylation of mTORC1 was contrary to the hypothesis in the current study. Although the precise mechanisms could not be discerned, enhanced Met supply increases feed intake and may increase AA flux into the mammary gland, which supports milk protein synthesis during the periparturient period via increases in AKT serine/threonine kinase 1 phosphorylation status and a cascade of intracellular events leading to upregulation of AA and glucose transporters, AA tRNA-synthases, insulin signaling, and Janus kinase 2 (JAK2)-signal transducer and activator of transcription 5 (STAT5) signaling. Coupled with increased feed intake, such events might have compensated for any reduction in ribosome biogenesis that might have occurred as a result of the lower phosphorylation status of RPS6 with enhanced Met supply. Further studies should be conducted to investigate whether Met supply has an effect on the activity of enzymes related to BCAA catabolism.

\section{ACKNOWLEDGMENTS}

Y. Ma and L. Han received China Scholarship Council (Beijing) postdoctoral fellowships to train at the University of Illinois (Urbana). Y. Liang is a recipient of a doctoral fellowship from the China Scholarship Council (Beijing, China). T. Xu received a China Scholarship Council (Beijing) doctoral fellowship to train at the University of Illinois (Urbana). F. Batistel was supported by a PhD fellowship from Coordenação de Aperfeiçoamento de Pessoal de Nível Superior (CAPES,
Brazilian Ministry of Education, Brasília, Brazil) and by Hatch funds under project ILLU-538-914, National Institute of Food and Agriculture (Washington, DC). We thank Perdue AgriBusiness (Salisbury, MD) for the donation of ProVAAl AADvantage during the course of the experiment.

\section{REFERENCES}

Abdelmagid, S. A., J. A. Rickard, W. J. McDonald, L. N. Thomas, and C. K. Too. 2011. CAT-1-mediated arginine uptake and regulation of nitric oxide synthases for the survival of human breast cancer cell lines. J. Cell. Biochem. 112:1084-1092.

Appuhamy, J. A. D. R. N., A. L. Bell, W. A. Deepthi Nayananjalie, J. Escobar, and M. D. Hanigan. 2011. Essential amino acids regulate both initiation and elongation of mRNA translation independent of insulin in MAC-T cells and bovine mammary tissue slices. J. Nutr. 141:1209-1215.

AOAC International. 1995. Official methods of analysis of AOAC International. 17th ed. AOAC International, Arlington, VA.

Backwell, F. R. C., B. J. Bequette, D. Wilson, J. A. Metcalf, M. F Franklin, D. E. Beever, G. E. Lobley, and J. C. MacRae. 1996. Evidence for the utilization of peptides for milk protein synthesis in the lactating dairy goat in vivo. Am. J. Physiol. 271:R955-R960.

Batistel, F., J. M. Arroyo, A. Bellingeri, L. Wang, B. Saremi, C. Parys, E. Trevisi, F. C. Cardoso, and J. J. Loor. 2017. Ethyl-cellulose rumen-protected methionine enhances performance during the periparturient period and early lactation in Holstein dairy cows. J. Dairy Sci. 100:7455-7467.

Bionaz, M., and J. J. Loor. 2007. Identification of reference genes for quantitative real-time PCR in the bovine mammary gland during the lactation cycle. Physiol. Genomics 29:312-319.

Bionaz, M., and J. J. Loor. 2008. Gene networks driving bovine milk fat synthesis during the lactation cycle. BMC Genomics 9:366.

Bionaz, M., and J. J. Loor. 2011. Gene networks driving bovine mammary protein synthesis during the lactation cycle. Bioinform. Biol. Insights 5:83-98.

Cant, J. P., J. J. Kim, S. R. Cieslar, and J. Doelman. 2018. Symposium review: Amino acid uptake by the mammary glands: Where does the control lie? J. Dairy Sci. 101:5655-5666.

Caron, A., D. Richard, and M. Laplante. 2015. The roles of mTOR complexes in lipid metabolism. Annu. Rev. Nutr. 35:321-348.

Chen, Y.-Y., F. J. Rosario, M. A. Shehab, T. L. Powell, M. B. Gupta, and T. Jansson. 2015. Increased ubiquitination and reduced 
plasma membrane trafficking of placental amino acid transporter SNAT-2 in human IUGR. Clin. Sci. (Lond.) 129:1131-1141.

Closs, E. I., J.-P. Boissel, A. Habermeier, and A. Rotmann. 2006. Structure and function of cationic amino acid transporters (CATs). J. Membr. Biol. 213:67-77.

Cui, H., B. Chen, L. G. Chicoine, and L. D. Nelin. 2011. Overexpression of cationic amino acid transporter-1 increases nitric oxide production in hypoxic human pulmonary microvascular endothelial cells. Clin. Exp. Pharmacol. Physiol. 38:796-803.

De Koster, J., R. K. Nelli, C. Strieder-Barboza, J. de Souza, A. L. Lock, and G. A. Contreras. 2018. The contribution of hormone sensitive lipase to adipose tissue lipolysis and its regulation by insulin in periparturient dairy cows. Sci. Rep. 8:13378.

Dong, X., Z. Zhou, L. Wang, B. Saremi, A. Helmbrecht, Z. Wang, and J. J. Loor. 2018. Increasing the availability of threonine, isoleucine, valine, and leucine relative to lysine while maintaining an ideal ratio of lysine:methionine alters mammary cellular metabolites, mammalian target of rapamycin signaling, and gene transcription. J. Dairy Sci. 101:5502-5514.

Galindo, C., M. Larsen, D. R. Ouellet, G. Maxin, D. Pellerin, and H. Lapierre. 2015. Abomasal amino acid infusion in postpartum dairy cows: Effect on whole-body, splanchnic, and mammary glucose metabolism. J. Dairy Sci. 98:7962-7974.

Giallongo, F., M. Harper, J. Oh, J. Lopes, H. Lapierre, R. Patton, C. Parys, I. Shinzato, and A. Hristov. 2016. Effects of rumen-protected methionine, lysine, and histidine on lactation performance of dairy cows. J. Dairy Sci. 99:4437-4452.

González, M., V. Gallardo, N. Rodríguez, C. Salomón, F. Westermeier, E. G. Gutiérrez, F. Abarzúa, A. Leiva, P. Casanello, and L. Sobrevia. 2011. Insulin-stimulated L-arginine transport requires SLC7A1 gene expression and is associated with human umbilical vein relaxation. J. Cell. Physiol. 226:2916-2924.

Hosoi, T., K. Hyoda, Y. Okuma, Y. Nomura, and K. Ozawa. 2007. Akt up- and down-regulation in response to endoplasmic reticulum stress. Brain Res. 1152:27-31.

Invernizzi, G., A. Naeem, and J. J. Loor. 2012. Endoplasmic reticulum stress gene network expression in bovine mammary tissue during the lactation cycle. J. Dairy Sci. 95:2562-2566.

Kaufman, R. J., D. Scheuner, M. Schröder, X. Shen, K. Lee, C. Y. Liu, and S. M. Arnold. 2002. The unfolded protein response in nutrient sensing and differentiation. Nat. Rev. Mol. Cell Biol. 3:411.

Lacasse, P., V. Farr, S. Davis, and C. Prosser. 1996. Local secretion of nitric oxide and the control of mammary blood flow. J. Dairy Sci. 79:1369-1374.

Lean, I. J., M. B. de Ondarza, C. J. Sniffen, J. E. P. Santos, and K. E. Griswold. 2018. Meta-analysis to predict the effects of metabolizable amino acids on dairy cattle performance. J. Dairy Sci. 101:340-364

Lee, S. W., B. H. Cho, S. G. Park, and S. Kim. 2004. Aminoacyl-tRNA synthetase complexes: Beyond translation. J. Cell Sci. 117:37253734 .

Li, L., M. L. He, K. Wang, and Y. Zhang. 2018. Buffering agent via insulin mediated activation of PI3K/AKT signaling pathway to regulate lipid metabolism in lactating goats. Physiol. Res. 67:753-764.

Li, S., A. Hosseini, M. Danes, C. Jacometo, J. Liu, and J. J. Loor. 2016. Essential amino acid ratios and $\mathrm{mTOR}$ affect lipogenic gene networks and miRNA expression in bovine mammary epithelial cells. J. Anim. Sci. Biotechnol. 7:44.

Loor, J. J., M. Bionaz, and J. K. Drackley. 2013. Systems physiology in dairy cattle: Nutritional genomics and beyond. Annu. Rev. Anim. Biosci. 1:365-392. https://doi.org/10.1146/annurev-animal $-031412-103728$.

Mackenzie, B., and J. D. Erickson. 2004. Sodium-coupled neutral amino acid (System N/A) transporters of the SLC38 gene family. Pflugers Arch. 447:784-795.

Malhotra, J. D., and R. J. Kaufman. 2007. Endoplasmic reticulum stress and oxidative stress: A vicious cycle or a double-edged sword? Antioxid. Redox Signal. 9:2277-2293.

Manjarin, R., B. J. Bequette, G. Wu, and N. L. Trottier. 2014. Linking our understanding of mammary gland metabolism to amino acid nutrition. Amino Acids 46:2447-2462.
Mann, S., F. L. Yepes, M. Duplessis, J. Wakshlag, T. Overton, B. Cummings, and D. Nydam. 2016. Dry period plane of energy: Effects on glucose tolerance in transition dairy cows. J. Dairy Sci. 99:701-717.

McGuire, M. A., J. M. Griinari, D. A. Dwyer, and D. E. Bauman. 1995. Role of insulin in the regulation of mammary synthesis of fat and protein. J. Dairy Sci. 78:816-824.

Nardi, F., T. Hoffmann, C. Stretton, E. Cwiklinski, P. M. Taylor, and H. S. Hundal. 2015. Proteasomal modulation of cellular SNAT2 (SLC38A2) abundance and function by unsaturated fatty acid availability. J. Biol. Chem. 290:8173.

Osorio, J. S., P. Ji, J. Drackley, D. Luchini, and J. J. Loor. 2013. Supplemental Smartamine M or MetaSmart during the transition period benefits postpartal cow performance and blood neutrophil function. J. Dairy Sci. 96:6248-6263.

Osorio, J. S., E. Trevisi, P. Ji, J. K. Drackley, D. Luchini, G. Bertoni, and J. J. Loor. 2014. Biomarkers of inflammation, metabolism, and oxidative stress in blood, liver, and milk reveal a better immunometabolic status in peripartal cows supplemented with Smartamine M or MetaSmart. J. Dairy Sci. 97:7437-7450.

Overton, T. R., D. W. LaCount, T. M. Cicela, and J. H. Clark. 1996. Evaluation of a ruminally protected methionine product for lactating dairy cows. J. Dairy Sci. 79:631-638.

Özcan, U., Q. Cao, E. Yilmaz, A.-H. Lee, N. N. Iwakoshi, E. Özdelen, G. Tuncman, C. Görgün, L. H. Glimcher, and G. S. Hotamisligil. 2004. Endoplasmic reticulum stress links obesity, insulin action, and type 2 diabetes. Science 306:457-461.

Pauloin, A., and E. Chanat. 2012. Prolactin and epidermal growth factor stimulate adipophilin synthesis in $\mathrm{HC} 11$ mouse mammary epithelial cells via the PI3-kinase/Akt/mTOR pathway. Biochim. Biophys. Acta 1823:987-996.

Porstmann, T., C. R. Santos, B. Griffiths, M. Cully, M. Wu, S. Leevers, J. R. Griffiths, Y. L. Chung, and A. Schulze. 2008. SREBP activity is regulated by mTORC1 and contributes to Akt-dependent cell growth. Cell Metab. 8:224-236.

Rico, J. E., W. A. Myers, D. J. Laub, A. N. Davis, Q. Zeng, and J. W. McFadden. 2018. Hot topic: Ceramide inhibits insulin sensitivity in primary bovine adipocytes. J. Dairy Sci. 101:3428-3432.

Rius, A. G., J. Appuhamy, J. Cyriac, D. Kirovski, O. Becvar, J. Escobar, M. McGilliard, B. Bequette, R. Akers, and M. Hanigan. 2010. Regulation of protein synthesis in mammary glands of lactating dairy cows by starch and amino acids. J. Dairy Sci. 93:3114-3127.

Ron, D., and P. Walter. 2007. Signal integration in the endoplasmic reticulum unfolded protein response. Nat. Rev. Mol. Cell Biol. 8:519-529.

Rosario, F. J., K. G. Dimasuay, Y. Kanai, T. L. Powell, and T. Jansson. 2016. Regulation of amino acid transporter trafficking by mTORC1 in primary human trophoblast cells is mediated by the ubiquitin ligase Nedd4-2. Clin. Sci. (Lond.) 130:499-512.

Schwab, C. G. 1995. Protected proteins and amino acids for ruminants. Biotechnology in Animal Feeds and Animal Feeding. R. J. Wallace and A. Chesson, ed. VCH Veragsgesellschafe, Weinheim, Germany, and VCH Publishers Inc., New York, NY.

Shimomura, Y., T. Honda, M. Shiraki, T. Murakami, J. Sato, H Kobayashi, K. Mawatari, M. Obayashi, and R. A. Harris. 2006. Branched-chain amino acid catabolism in exercise and liver disease. J. Nutr. 136:250S-253S.

Sundberg, B. E., E. Wååg, J. A. Jacobsson, O. Stephansson, J. Rumaks, S. Svirskis, J. Alsiö, E. Roman, T. Ebendal, and V. Klusa. 2008. The evolutionary history and tissue mapping of amino acid transporters belonging to solute carrier families SLC32, SLC36, and SLC38. J. Mol. Neurosci. 35:179-193.

Toerien, C. A., D. R. Trout, and J. P. Cant. 2010. Nutritional stimulation of milk protein yield of cows is associated with changes in phosphorylation of mammary eukaryotic initiation factor 2 and ribosomal s6 kinase 1-3. J. Nutr. 140:285-292.

Tucker, H. A., M. D. Hanigan, J. Escobar, P. H. Doane, and S. S. Donkin. 2017. Hepatic expression of aminoadipate semialdehyde synthase is unchanged by postruminal lysine supply in lactating dairy cows. J. Dairy Sci. 100:1009-1018. 
Winkelman, L. A., and T. Overton. 2013. Long-acting insulins alter milk composition and metabolism of lactating dairy cows. J. Dairy Sci. 96:7565-7577.

Wolfson, R. L., and D. M. Sabatini. 2017. The dawn of the age of amino acid sensors for the mTORC1 pathway. Cell Metab. 26:301-309.

Wullschleger, S., R. Loewith, and M. N. Hall. 2006. TOR signaling in growth and metabolism. Cell 124:471-484.

Yecies, J. L., H. H. Zhang, S. Menon, S. Liu, D. Yecies, A. I. Lipovsky C. Gorgun, D. J. Kwiatkowski, G. S. Hotamisligil, C. H. Lee, and B. D. Manning. 2011. Akt stimulates hepatic SREBP1c and lipogenesis through parallel mTORC1-dependent and independent pathways. Cell Metab. 14:21-32.

Zachut, M., H. Honig, S. Striem, Y. Zick, S. Boura-Halfon, and U. Moallem. 2013. Periparturient dairy cows do not exhibit hepatic insulin resistance, yet adipose-specific insulin resistance occurs in cows prone to high weight loss. J. Dairy Sci. 96:5656-5669.

Zhang, T., J. Huang, Y. Yi, X. Zhang, J. J. Loor, Y. Cao, H. Shi, and J. Luo. 2018. Akt serine/threonine kinase 1 regulates de novo fatty acid synthesis through the mammalian target of rapamycin/sterol regulatory element binding protein 1 axis in dairy goat mammary epithelial cells. J. Agric. Food Chem. 66:1197-1205.

Zhao, F. Q. 2014. Biology of glucose transport in the mammary gland. J. Mammary Gland Biol. Neoplasia 19:3-17.
Zhao, F. Q., and A. Keating. 2007. Expression and regulation of glucose transporters in the bovine mammary gland. J. Dairy Sci 90:E76-E86.

Zhao, F. Q., P. J. Miller, E. H. Wall, Y. C. Zheng, B. Dong, M. C. Neville, and T. B. McFadden. 2004. Bovine glucose transporter GLUT8: Cloning, expression, and developmental regulation in mammary gland. Biochim. Biophys. Acta 1680:103-113.

Zhao, Y., C. Johansson, T. Tran, R. Bettencourt, Y. Itahana, P. Y. Desprez, and S. F. Konieczny. 2006. Identification of a basic helixloop-helix transcription factor expressed in mammary gland alveolar cells and required for maintenance of the differentiated state. Mol. Endocrinol. 20:2187-2198.

Zhou, Z., O. Bulgari, M. Vailati-Riboni, E. Trevisi, M. A. Ballou, F. C. Cardoso, D. N. Luchini, and J. J. Loor. 2016a. Rumen-protected methionine compared with rumen-protected choline improves immunometabolic status in dairy cows during the peripartal period. J. Dairy Sci. 99:8956-8969. https://doi.org/10.3168/jds.2016 -10986 .

Zhou, Z., M. Vailati-Riboni, E. Trevisi, J. K. Drackley, D. N. Luchini, and J. J. Loor. 2016b. Better postpartal performance in dairy cows supplemented with rumen-protected methionine compared with choline during the peripartal period. J. Dairy Sci. 99:8716-8732. https://doi.org/10.3168/jds.2015-10525. 